\title{
第19回群馬整形外科研究会
}

\section{〈主題 I〉}

人工材料 (骨内固定材料, エンドプロステーシ ス, 人工靱帯，骨補填材料など）を用いた術後 経過不良例

座長 : 高柳 聡 (サンピエール病院 整形外科)

1. 人工股関節再置換術後の脱臼に対して offset head の使用が有効であった 1 例

O園田 裕之，割田 敏朗，佐藤 貴久

高岸 憲二 (群馬大院・医・整形外科学)

症例は 73 歳女性である. 両側変形性股関節症に対し て 1993 年 3 月，9月にそれぞれ人工股関節置換術を受 け，その後の経過観察に扔いて徐々㲹右大腿部痛や左殿 部痛の自覚と X-p 上の implant 周囲の osteolysis の進行 を認めた. 右大腿部痛と osteolysisによる大腿骨骨折発 症の危惧から 2010 年 10 月に再置換術を施行した。術後 2 週の未明にトイレでの転倒によって後方脱臼を発症し， 同日全身麻醉下に徒手整復術を行った. 術後 6 週からは 他院での入院リハビリテーションを継続となったが, 術 後 7 週に右股関節の違和感を自覚され，そのさらに 1 週 後に X-p 上の後方脱臼 (2 回目) が明らかとなった. 当院 へ搬送後の全身麻酔下徒手整復術では整復不能であった ため, 術後 9 週に観血的整復術を行った. 前回の術中評 価よりも後方への不安定性が認められ，cup 前方頭側と stem neck との impingementに対して offset head を用い ることで安定性の改善を得た，再久置換術後 4 週に自宅 へ退院となり，術後2ヶ月の現在まで再脱臼を生じてい ない.

\author{
日 時：2011 年 6 月 18 日 (土) \\ 場所：群馬大学医学部内臨床中講堂 \\ 代表世話人 : 高岸 憲二 (群馬大院・医・整形外科学)
}

\section{T K A 術後の荷重開始時期の違いは, 術後血栓症の} 発症に影響を及ぼすか

O大倉 千幸, 畑山 和久, 寺内 正紀,
堤 智史, 中川 由美, 関 隆致

(群馬中央総合病院 整形外科)

【はじめに】 TKA 術後の深部静脈血栓症 (DVT) の発 症の予防には早期荷重が有用とされている一方で, 早期 荷重による肺血栓塞栓症 (PTE) の発症が問題となる. 今 回我々は, 荷重開始時期の差により DVT・PTE の発症率 に差があるかを検討した。【対象と方法】術後 2 日で 荷重する A 群と 1 週で荷重する B 群に分け, さらに各群 を, 抗凝固薬を 5 日以上継続投与した群と 4 日以内に出 血イベント等で中断した群とに分け, 1 週の D ダイマー 值とDVT・PTEの発症率を比較した。【結 果】荷重 訓練の開始時期は DVT・PTE の発症䅫影は及ほさざ, 抗凝固薬を継続できた症例で術後 $1 \mathrm{w}$ の D ダイマー值 は有意に低加た。【考 察】TKAの術後血栓症予防 には早期荷重単独では十分な効果はなく, 抗凝固薬の使 用が重要であると思われた。

\section{3．踵骨剝離骨折の治療経験}

○武智 瑠美, 鈴木 秀喜, 有田 覚 (県立心臟血管センター 整形外科)

踵骨骨折の中で, アキレス腱付着部の剝離骨折は比較 的まれである. 治療として，骨片をスクリューで固定し た報告をしばしば認めるが，合併症の報告も多い.今回, 踵骨アキレス腱付着部剥離骨折を 3 例 4 足を経験したの で報告する.【症例 1】57歳，女性. 階段より転落して 受傷. 4 日後に近医受診し当院紹介受診, 入院. Xp 上, 左 踵骨アキレス腱付着部剝離骨折・脛骨内果骨折を認めた。 受傷後 7 日目に手術施行. 内果は 4.0 canulated cancellous screw (MDM) で，踵骨はワッシャー付き 6.5 canulated cancellous screw (MDM) で固定した. 術後 4 週から ROM ex と, PTB 装着し歩行開始. 術後 7 週から 装具内部分荷重を開始し術後 9 週で装具除去し全荷重と した. 術後 3 週で創部潰瘍形成あり薬浴処置を開始し, 
術後 5ケ月で創治癒が得られた。【症例 2】52 歳, 男 性. トラックの荷台から飛び降りて両アキレス腱部の疼 痛出現. 翌日近医受診し, 両側アキレス腱断裂疑いにて 当院へ紹介され, 入院した. $\mathrm{Xp} ・ \mathrm{CT} ・ \mathrm{MRI}$ で両側ともご く薄い剝離骨片を伴ったアキレス腱付着部剝離骨折であ り, 受傷後 13 日目に手術施行. 両側ともスーチャーアン カー (Mitek Fastin RC $6.5 \mathrm{~mm} \times 2)$ を用いてアキレス腱 を修復した. 術後 5 週より ROM ex を開始し術後 6 週よ り部分荷重開始, 術後 8 週より全荷重を許可した. 術後 の合併症は特になかった。【症例 3】93歳, 女性. 土手 を歩いていてつまずき $1 \mathrm{~m}$ ほど転落し受傷. 翌日近医受 診し, 当院へ紹介され入院. $\mathrm{Xp}$ 上, 左アキレス腱付着部 剝離骨片を認めた。受傷後 9 日目に手術施行. スー チャーアンカー (Mitek Fastin RC $6.5 \mathrm{~mm} \times 2$ ) を用いて ORIF. 術後 3 週よりROM を開始し術後 4 週上り歩行 用ギプスで部分荷重開始. 術後 6 週で全荷重を許可し術 後 7 週にギプス除去した. 術後の合併症は特になかった. 【考 察】踵骨アキレス腱付着部剝離骨折の手術療法と してはワッシャー付き海面骨スクリューでの固定が一般 的であるが，アキレス腱の率引力や骨の脆弱性が関与し ているため, 骨片が割れてしまったり骨片の再転位が生 じやすく, 皮膚壊死などの合併症もしばしば報告されて いる. 我久の症例でも, スクリューを用いて固定した症 例では皮膚壞死のため長期間の処置を必要とした。他の 2 症例ではスーチャーアンカーを用いたところ，とくに 合併症は見られず，良好な結果を得た。アキレス腱付着 部剝離骨折に対する内固定剤として, スーチャーアン カーは有用であると考えられた。

\section{4.コーン型セメントレスステム(LIMA modulus)の使} 用経験

\section{○鈴木 隆之, 永井 彩子, 武智 泰彦 \\ 佐藤 直樹, 小林 史明, 田中 宏志}

(伊勢崎市民病院整形外科)

【目 的】 大腿骨頝部骨折に対して骨接合術を施行後, 偽関節や近位骨片の再転位例，また，大腿骨頸部外側骨 折保存的治療後の例で大腿骨骨皮質が菲薄化しストーブ パイプ状を呈した症例に対してコーン型セメントレスス テムを使用し短期ではあるが良好な成績を扔さめたので 報告する。【方 法】 LIMA 社 modulus stem を用い た.【症 例】(1)大腿骨転子部骨折, 骨接合術後 4r月, 偽関節(2)大腿骨頸部内側骨折ハンソンピン術後 1 年, 偽 関節・骨頭壊死(3)(4)大腿骨転子部骨折受傷後 9 ケ月, 1 年 5r月, 偽関節. 初診・手術は他院, 術後・保存療法後も他 院にてリハビリテーションを施行していたが, 疼痛を主 訴に当院受診となった。【結 果】術後 2 ケ月 1 年 5ケ月で, ステムのゆるみ/沈下は認めず歩行 (杖使用例
あり) 可能であり経過良好である.【考 察】骨皮質が 菲薄化したストーブパイプ型の大腿骨に対してはインプ ラントの選択に悩まされる. 今回使用したLIMA modulus stem は脆弱な骨質に対しても優れた固定性を 示しセメントレスステムとして有効な 1 手であると思わ れる。

\section{5. 当院における大腿骨頸基部・転子部骨折に対する ORIF での治療成績}

$\begin{array}{rrl}\text { O米山 } & \text { 友貴, 永野 } & \text { 賢一, 対比地加奈子 } \\ \text { 岡田 } & \text { 純幸, 反町 } & \text { 泰紀, 中島 飛志 } \\ \text { 内田 } & \text { 徹, 浅見 和義 } \\ & \text { (前橋赤十字病院 } & \\ & \text { 整形外科) }\end{array}$

当院は県内でも有数の外傷病院であり, 手術件数は年 間 800 件に迫る. その中で最も多いのが大腿骨䅡部頸基 部・転子部骨折である. 安定型の頸基部, 転子部骨折 (AO A1) に対しては, JMM 社製 K max (AA hip screw) を, 不 安定型の転子部骨折や転子下骨折 (AO A2-3) に対して は S \& N 社製 IMHS を主に扱っている。 また, 転子下未 梢へ骨折線が伸びるようなものには Long typeを用いて いる.

今回, $\mathrm{H} 22$ 年 1 月から 12 月に当院で経験した大腿骨 䅡基部, 転子部, 転子下骨折 (AO A1-3) の手術例におい て, 手術時間, 術後 $\mathrm{Hb}$ 低下量, telescoping 量などの比較 検討を行ったので報告する.

\section{6. 上腕骨頚部骨折術後に骨髄炎様症状を呈し, 治療に 難渋した症例}

\section{○喜多川 孝欽, 進上 泰明, 八田 範子 （館林厚生病院 整形外科）}

【はじめに】我々は上腕骨頝部骨折術後に骨髄炎様症状を 呈し，治療に難渋した症例を経験したので報告する。 【症 例】 74 歳, 女性. 平成 22 年 8 月 2 日, 右上腕骨頝 部骨折に対し観血的整復固定術を施行. 9 月 29 日に創よ り排膿を認め，急性骨髄炎を疑い，10月 4 日に抜鎬術施 行. 術後, 創が再離開し, 炎症性肉芽の増生, 血性滲出液 を認め, 11 月 2 日に洗浄㧍よびデブリードマンを施行. 創の一部が癒合せず，11月 9 日から生理食塩水による洗 浄を連日行った. 初回の排膿時より細菌培養を計 4 回 行ったが, 真菌, 好酸菌を含め全て陰性であった. 金属ア レルギーを疑い，11月 27 日から抗ヒスタミン薬を開始. 12 月 6 日に創瘾合が得られた。【結 語】骨髄炎様症 状を呈した症例を経験した。 鑑別疾患として金属アレル ギーが挙げられる. 
〈主題 II〉

\section{一般演題}

座長：萩原 明彦（公立藤岡総合病院 整形外科)

7. 骨端線閉鎖前の小児に対する $A C L$ 再建術

○小泉 裕之，木村 雅史，小林 保一

萩原 敬一, 大澤 貴志

（善衆会病院 群馬スポーツ医学研究所）

【目 的】骨端線閉鎖前の ACL 損傷に対する再建術は いまだ議論のあるところである.われわれは，骨端線閉 鎖前の小児に対して骨端線を貫通しない ACL 再建術の 治療成績を報告する。【対象と方法】骨端線閉鎖前の 小児 6 例 6 膝 (男児 4 例, 女児 2 例) に対して, 2 重折り の半腱様筋腱 (ST) を用いた 2 束 $\mathrm{ACL}$ 再建術を行った. 手術時年齢は平均 14.2 歳 (13 歳〜 16 歳) であった. 術前 MRI でT2*で骨端線が高輝度線状陰影を示す場合を骨 端線閉鎖前と判定した．臨床成績は Lachman test と Ntest, ストレス撮影での患健差 (Telos SE), Lysholm score を用いて評価した. 脚長差や骨変形は下肢 X 線により観 察した.【結 果】経過観察期間は平均 30.5 力月であ る. Lachman test は全例陰性, N-test は 4 例陰性, 2 例偽 陽性であった. ストレス撮影での患健差 (Telos SE) は平 均 $10.2 \mathrm{~mm}$ から $3.0 \mathrm{~mm}$ に改善した. Lysholm score は平 均 51 点から 93.7 点に改善した. 1 例は受傷前と同様の 身体活動レベルに回復できなかった. 1 例に再断裂が生 じた，有意な成長障害は認められなかった。【結 論】 ST による骨端線を貫通しない ACL 再建術は競技活動 の制限を望まない骨端線閉鎖前の小児に対して有用であ ると思われた。

\section{8. 踵骨骨棘の裂離骨折を伴ったアキレス腱断裂の 1 例 ○柳澤 信明，大澤 敏久，高澤 英嗣 新井厚}

(高崎総合医療センター 整形外科)

アキレス腱断裂は日常しばしば遭遇する外傷である が，今回非常に稀であると報告されている踵骨骨棘の裂 離骨折を伴った断裂を経験したので報告する。【症 例】 63 歳男性. 野球の試合中に走畋をしていた際に受 傷した.アキレス腱踵骨付着部に陥凹を触知し，同部位 に圧痛を認め, Thompson test は陽性であった. 単純 X 線 側面像にてアキレス腱内の石灰化像，また踵骨骨棘から 裂離したと思われる骨片を認めた。手術所見では,アキ レス腱は浅層は踵骨骨棘の裂離骨折であり，内側の一部 は腱様部で mop-end 様の断裂であり, 深層は付着部での 断裂であった，踵骨付着部に骨孔を作成して縫合した。
後療法は通常のアキレス腱断裂に準じて行った。術後 4ヶ月経過しているが, 疼痛なく, ADL 上特に支障は見 られていない。

9. 化膿性足関節炎を合併した小児脛骨骨髄炎の一例 O近藤 尚行, 角田 大介, 久保井卓郎 高橋 敦志, 小野 秀樹, 萩原 明彦 (公立藤岡総合病院 整形外科)

小児骨関節感染症は初期症状が非特異的であり, 整形 外科を初診することは少ない．また軟部感染症と区別し づらいなどにより, 早期発見治療に結びつかないことが 多い。【症 例】1歳女児, 左下腿から足部にかけての 腫脹, 歩行困難, 発熱にて近医整形外科上り蜂窩織炎疑 いで紹介となった，下肢に広範な発赤と足関節不動を認 め, CRP12.9, 赤沈 100, Xp にて骨病変指摘できず, 血液 培養は陰性であった.軟部組織や骨，関節の感染症を疑い 抗生剂開始した. 入院後の MRI にて下腿骨髄浮腫, 足関 節液貯留を認め, 脛骨骨䯣炎, 化膿性足関節炎疑いにて 切開, 排膿術施行した. 混濁した関節液がひけ, 培養にて 黄色ブドウ球菌十であった. 入院直後より CTM，その後 PAPM/BP を投与, 6 週後に CRP 陰性, 赤沈 24 , 荷重可 となり退院となった. 入院後 Xpでは骨幹端に溶骨病変 を認め, 経過とともに病変が骨端部に進行していった.

発熱, 痛がって歩行しないなどの訴えがあるときは, 局所所見や Xp 異常の有無にかかわらず, 骨関節感染症 の可能性を考元, 早期からの抗生物質投与が重要と思わ れた。

10. 脛骨近位部粉砕骨折に対し, TRIGEN META-NAIL を用い脛骨髄内釘固定を行った 3 例

○下山 大輔, 片山 雅義, 足立 智 斯波 俊祐

（桐生厚生総合病院 整形外科）

【はじめに】脛骨近位部粉砕骨折に対し, TRIGEN META-NAIL を用い, 上膝蓋アプローチによる膝伸展位 での脛骨髄内釘手術を 3 症例経験したので報告する。 【症例 1】 30 歳男性. 平成 22 年 9 月 11 日バイクによる 交通事故で受傷. 初診時, 右脛骨近位部粉砕骨折, 右腓骨 骨折, 右股関節脱臼骨折，右足関節内果骨折，右第 5 中足 骨骨折，右踵部挫滅創が認められた。 同日，右股関節脱臼 に対し, 非観血的整復施行した. 9 月 28 日右脛骨骨折に 対し上記髄内定を用い固定術を施行した。術後 6 週より トーマス装具装着し, 歩行訓練開始した。現在は, 術後尖 足拘縮のため, 他院で加療中である.【症例 2】39歳 男性. 平成 22 年 10 月 21 日バイクによる交通事故で受 傷. 初診時, 右脛骨近位部㧍よび骨幹部開放性骨折, 右腓 骨骨折, 後脛骨動脈損傷が認められた。 同日, 脛骨に対し 
経皮的鋼線刺入術, 腓骨に対し観血的整復固定術, 血管 縫合術, ほかに筋膜切開術および膝関節内洗浄を施行し た. 11 月 9 日右脛骨骨折に対し上記䯣内釬を用い固定術 を施行した。術後 6 週よりトーマス装具装着し, 歩行訓 練開始した. 現在は, 装具内部分荷重で, 近日中に装具を 外す予定である.【症例 3】59歳男性. 平成 22 年 11 月 16 日自動車による交通事故で受傷. 初診時, 右脛骨近 位部開放性骨折, 右腓骨骨折, 右大腿骨骨幹部骨折, 左リ スフラン関節脱臼骨折, 左足関節脱臼骨折が認められた。 同日, 右大腿骨骨折, 右腓骨骨折に対し髄内釘刺入, 左リ スフラン脱臼骨折に対し，経皮的鋼線刺入を行った. 11 月 30 日右脛骨骨折に対し上記髄内釷を用い固定術施行 した. 左下肢は第 2 回手術の 4 週後から荷重開始した. 右下肢は術後 7 週よりトーマス装具装着し, 歩行訓練開 始した. 現在は, 装具内荷重で, 近日中に装具を外す予定 である.【結 語】脛骨近位粉砕骨折に対し, 上膝蓋ア プローチによる膝伸展位での脛骨髄内釬固定で良好な固 定が得られた。

\section{1. 腓骨筋腱脱臼に対して Akiki 法を施行した 1 例 ○山口 蔵人, 久保田 仁, 須藤 執道 (堀江病院 整形外科)}

比較的稀な腓骨筋腱脱臼に対して Akiki 法を施行し, 良好な結果を得たので報告する。【症 例】17 歳男性 (野球部), $\mathrm{H} 19$ 年 8 月走行中に急停止した際足関節背側 強制され, 腓骨筋腱脱臼を起こす. その後左右に動く際 脱臼を繰り返し, 受傷後 7 週で当科初診. 初診時足関節 背屈位にて腓骨筋腱は容易に脱臼し, 腓骨筋腱脱臼の診 断にて9週で Akiki 法を施行. Akiki 法は腱床を陥凹さ せる手術法の一つで, 腓骨後方の腱床を骨軟部組織ごと 陥凹させる. 術後 2 週で全荷重を許可し, 4 週でギプス除
去, 夏の大会には出場した。【考 察】腓骨筋腱脱臼に 対する手術は軟部組織を修復するもの, 腓骨を骨切りし て骨性防壁を作るもの, 腓骨腱床を陥凹させるものなど がある. 本法は腓骨腱床の骨軟部組織を一塊にて陥凹さ せる方法で, 内固定を必要とせず早期より可動域訓練や 荷重歩行が可能であり，腓骨部の違和感が少ないなどの 利点が多い. 早期復帰を目指すスポーツ選手には特に有 用な手技と思われた。

\section{2. 非外傷性頚俱道硬膜外血腫の 2 例 \\ O勝見 賢 (深谷赤十字病院 整形外科) \\ 萩原 明彦，小野 秀樹 \\ (公立藤岡総合病院 整形外科)}

外傷の既往なく頝部の痛みで発症し, 急激な麻痺の進 行のため, 緊急手術を行った頝䯑道硬膜外血腫を経験した ので報告する.【症例 1】60歳女性. 後ろを振り向い た瞬間に頝部に激痛が生じ, 徐々に呼吸苦も出現してき たため救急搬送された，救急外来にて急速に四肢麻㽻の 進行を認めたため MRI を施行し, 頝䯣硬膜外血腫と診 断し緊急手術 (頝椎椎弓形成術十血腪除去術) を行った。 現在は, 頝部の軽い違和感の他, 後遺症なく日常生活を 送っている.【症例 2】68歳男性. 既往に C 型肝炎, 肝 硬変がある. 夜寝ようとした瞬間に頝部に激痛が走り, 右上下肢の脱力が生じ救急搬送された。脳梗塞が疑われ 内科にて頭部 CT, MRI が施行されたが, 所見なく経過 観察入院となった。 翌日になり, 左上下肢の麻痺も出現 したため整形外科コンサルトとなった. MRI にて頝唱硬 膜外血腫と診断し緊急手術を行ったが, 麻痺の回復は十 分でなく, 日常生活において, 介護を要する状態である. 頝髄硬膜外血腫は片側の麻痺で発症することもあり, 脳 血管疾患と紛らわしく, 注意が必要であると感じた。 